\title{
THE EFFECT OF COVID-19 ON THE FINANCIAL PERFORMANCE OF INDONESIA'S LIVESTOCK INDUSTRY
}

\author{
Maghfira Puti Gaisani*), Idqan Fahmi*), Hendro Sasongko ${ }^{* *}$ \\ ${ }^{*}$ School of Business, IPB University \\ Jl. Pajajaran Bogor 16151, Indonesia \\ ${ }^{* *}$ Faculty of Economics and Business, Pakuan University \\ Jl. Pakuan PO Box 452 Bogor 16143, Indonesia
}

\begin{abstract}
This study aims to analyze the impact of COVID-19 on the financial performance of Indonesia's poultry industry companies. The samples used in this study were broiler farming companies of XYZ Group from September 2019 to August 2020. Financial performance is used as the dependent variable to see the effect of the independent on the dependent. The independent variables in this study are leverage, liquidity, revenue, profitability, firm size, and COVID-19. The analytical method used is descriptive analysis with a quantitative approach. In this study, a z-score test, regression test, and internal firm interviews supported the results. The results showed that there were indications of problems with the firm's financial health. COVID-19 does not significantly affect its financial performance, but several other factors influence it, namely revenue, profitability, and firm size. Several forms of strategies that can be formulated for companies are maintaining cash flow by extending the debt period and shortening accounts receivable to restore the firm's financial health. Then make efficiency in the cost of goods sold and improve operational cooperation to improve the firm's financial performance. Companies can also increase funding by obtaining additional capital from a holding company before financing from outside parties.
\end{abstract}

Keywords: COVID-19, financial distress, financial performance, poultry business, return on asset

\begin{abstract}
Abstrak: Penelitian ini bertujuan menganalisis dampak COVID-19 terhadap kinerja keuangan perusahaan industri perunggasan di Jawa Barat. Sampel yang digunakan dalam penelitian ini adalah perusahaan peternakan broiler XYZ Group dari September 2019 hingga Agustus 2020. Kinerja keuangan digunakan sebagai variabel dependen untuk melihat pengaruh antara independen terhadap dependen. Variabel independen dalam penelitian ini adalah leverage, likuiditas, revenue, profitabilitas, ukuran perusahaan, dan COVID-19. Metode analisis yang digunakan adalah analisis deskriptif dengan pendekatan kuantitatif. Penelitian ini menggunakan uji z-score dan uji regresi serta wawancara internal perusahaan untuk mendukung hasil regresi tersebut. Hasil penelitian menunjukkan bahwa terdapat indikasi masalah pada kesehatan keuangan perusahaan. COVID-19 tidak berpengaruh signifikan terhadap kinerja keuangannya, namun terdapat beberapa faktor lain yang mempengaruhi kinerja keuangan perusahaan yaitu pendapatan, profitabilitas, dan ukuran perusahaan. Beberapa bentuk strategi yang dapat dirumuskan bagi perusahaan adalah menjaga arus kas dengan memperpanjang masa hutang dan memperpendek piutang untuk memulihkan kesehatan keuangan perusahaan. Kemudian melakukan efisiensi pada harga pokok penjualan dan meningkatkan kerjasama operasional untuk meningkatkan kinerja keuangan perusahaan. Perusahaan juga dapat memperoleh suntikan modal melalui perusahaan holding sebelum memperolehnya dari luar.
\end{abstract}

Kata kunci: bisnis perunggasan, COVID-19, financial distress, kinerja keuangan, return on asset

${ }^{1}$ Corresponding author:

Email: maghfira62@apps.sb.ipb.ac.id 


\section{INTRODUCTION}

In Indonesia, the poultry farming industry continues to develop, especially in the broiler industry. The potential market in the broiler business in Indonesia still has a huge gap when viewed based on the chicken meat consumption level per capita of Indonesia, which is much lower than that of other ASEAN countries. It makes the broiler business attractive, promising (Bahari et al. 2012) and competitive (Maisana et al. 2012) According to the OECD (2020), in 2019, the level of chicken meat consumption in Indonesia is still lower when compared to ASEAN countries, which is only 7 kilograms per capita, while Malaysia has reached 48.7 kilograms per capita.

The population of broiler poultry in Indonesia places the top rank compared to other poultry such as domestic chickens, laying hens, ducks, and manila ducks. The population of broilers increased by $7.36 \%$ in 2019 (Ditjennak, 2020). The large population of Indonesian broilers mostly comes from West Java, which reached $25 \%$ of the total production of Indonesian broilers in 2019 .

The broiler business has high risk, especially fluctuating input and output prices, making farmers' income unstable (Bahari et al. 2012). One of the causes is a trend or phenomenon that occurs in society, including a phenomenon of the COVID-19 pandemic worldwide, which was first announced in Indonesia on March 2, 2020 .

To mitigate the spread of the COVID-19 pandemic, the Indonesian government has officially issued a regulation related to physical distancing through the PERMENKES RI Number 9 of 2020 concerning Pedoman Pembatasan Sosial Berskala Besar (Guidelines for Large-Scale Social Restrictions) to accelerate the handling of the COVID-19 pandemic. One of the regulations issued is the Large-Scale Social Restrictions (PSBB) policy on April 3, 2020, and came into effect on April 10, 2020. The schools and workplaces are required to close faceto-face learning and work activities. The government also limits activities in places of worship. Previously, WHO established a physical distancing policy through the Emergencies Coronavirus Press Conference on March 20, 2020.
Since the implementation of the PSBB, community demand for livebird has decreased (Pinsar, 2020). The price of broiler rebounded again in the period leading up to the Eid holidays, namely in May and June 2020. The decline and increase in the price of broiler was also caused by the public demand for broiler (Pinsar, 2020). Compared to the price of broilers in 2020 with previous years, the price of broilers in 2020 has a pretty different price trend. The price of broiler in April 2017, 2018 and 2019 has increased, but in April 2020 the price of broiler has decreased because of the implementation of PSBB. It also occurred in June 2017, 2018 and 2019, the price of broiler decreased, while in June 2020 the price of broiler increased because there is an Eid moment.

The price fluctuation of broilers and Day-Old Chicken (DOC) can disturb the financial health or performance of broiler breeders and broiler companies, including companies operating in West Java. One of the companies in the broiler field in West Java that is affected is XYZ Group companies.

XYZ Group is a group of companies engaged in the poultry industry with operational areas in West Java, Indonesia. XYZ Group has a broad business network, including farm or livestock, farm construction, slaughterhouse, food processing, trading, expeditor, and event organizer. XYZ Group adheres to the concept of self-reliance and partnership in its livestock business. Until 2020, XYZ Group has ten experienced veterinarians to support its business activities, 665 employees, 1852 breeders who partner and cooperate with XYZ Group, 1281 customers or chicken baskets, and monthly feed consumption reach up to 14,000 tons. The production capacity of broilers reaches $11,000,000$ birds per production cycle. In addition, XYZ Group has implemented a system of 1 recording on production and finance that is digital-based and integrated each other. XYZ Group has experienced a reasonably volatile increase and decrease in revenue. XYZ Group's income from the on-farm unit (a unit that cultivates broilers) in April 2020 decreased by $29 \%$ compared to the month's income before March 2020.

In previous research, it was explained that organizations or companies need to maintain their financial health to not end up in bankruptcy (Altman, 2006). Companies can analyze financial health based on firm financial data and use several ratios such as profitability, liquidity, and solvency to measure it (Outecheva, 2007). Based 
on Matar and Eneizan (2018) research, financial performance in companies is also affected by firm size, liquidity, revenue, profitability, and leverage. Aifuwa et al. (2020) also explained that COVID-19 affected the firm's financial performance. Research on the effect of COVID-19 on the firm's financial performance is still limited, such as research from Aifuwa et al. (2020), especially in the broiler farming industry. Therefore, in addition to using the variables of firm size, liquidity, revenue, profitability, and leverage; this study will also focus on the impact of COVID-19 on the firm's financial performance in broiler poultry companies.

Every company has a primary goal to achieve profits and provide high returns to shareholders. To achieve these goals, companies must have good financial health and performance. Financial health is part of the companies success. The income statement and balance sheet serve as an illustration for internal and external parties of the firm (Mohammed 2016). The firm's financial condition can become distressed. It happens when the firm experiences losses continuously (Andrade and Kaplan, 1998). Furthermore, financial distress can predict using the Z-score model (Outecheva, 2007; Altman, 1968).

Apart from financial distress analysis, a firm can also assess its performance with a profitability ratio that shows the firm's ability to generate profits. The profitability ratio is measured by common-size income statement, gross profit margin, operating profit margin, net profit margin, earning per share, return on total assets, and return on equity (Gitman and Zutter, 2015). The most commonly used measuring tools are ROA and ROE based on previous research from Palaniappan (2017), Assenga et al. (2018), and Matar and Eneizan (2018). In addition, several factors affect the firm's financial performance, namely the level of liquidity, leverage, revenue, profitability, firm size (Matar and Eneizan 2018), and COVID-19 (Aifuwa et al. 2020). Therefore, this study aims to see the financial performance of broiler farms companies before and during COVID-19, whether there was financial distress during those times. This study also aims to see what variables affect the firm's financial performance using combined variables based on previous studies by Assenga et al. (2018), Matar and Eneizan (2018), and Batchimeg (2017). Finally, this study also formulates the strategies that help to improve the firm's financial performance.

\section{METHODS}

This research was conducted at a broiler farms company at XYZ Group, which operates in West Java. Research time from December 2020 to January 2021. This study uses primary and secondary data. Primary data were obtained directly through in-depth interviews with several key informants, namely the XYZ Group board. Secondary data were obtained from the firm's financial statements for the period September 2019 to August 2020. The sample used in this study is a broiler breeding company from XYZ Group which publishes complete financial statements from September 2019 to August 2020.

This research is a quantitative study with a descriptive approach that explains the influence of the variables studied through data processing from the firm's financial statements into a form of information or a picture that is easy to understand. In addition to using data from financial statements, the analysis will also be supported using the Z-score model. The Z-score model can analyze the firm's financial health condition with the following model:

$$
\begin{aligned}
Z= & 0,717 X_{1}+0,847 X_{2}+3,107 X_{3}+0,420 X_{4}+ \\
& 0,998 X_{5}
\end{aligned}
$$

Description: $\quad \mathrm{X}_{1} \quad$ (Working capital/Total asset); $\mathrm{X}_{2}$ (Retained earning/ Total asset); $\mathrm{X}_{3}$ (earning before interest and taxes (EBIT)/ Total asset); $\mathrm{X}_{4}$ (book value of equity/ book value of total asset); $\mathrm{X}_{5}$ (Sales/ Total asset). The decision criteria for private companies: (1) $\mathrm{Z}>2,90$ : Safe zone, 1,23 $<\mathrm{Z}<2,90$ : Gray zone, and $\mathrm{Z}<1,23$ : Distress zone.

Financial health (financial health) becomes an important thing in running a firm. The income statement and balance sheet serve as an illustration for interested parties regarding the health condition of the firm. As the firm progresses, the firm's financial condition can distress. It happens when the firm experiences losses continuously (Andrade and Kaplan, 1998). According to Wruck (1990) and Mohammed (2016), financial distress is a condition in which the firm's cash flow cannot pay the firm's short-term or long-term debt.

Financial distress can be dire for the firm to the point of bankruptcy (Mohammed, 2016). According to Outecheva (2007) and Altman (1968), one of the accounting-based models used to predict financial 
distress is the Z-score model. According to Altman (1968), firm bankruptcies can be analyzed using financial statements and combining them with market value. Analysis using the $\mathrm{Z}$-score model and the score results can be used to classify companies into the bankrupt category.

Then, this study uses the panel data regression method to determine the variables that affect the firm's financial performance. The formulation of the regression model used in this study is as follows:

$$
\begin{aligned}
R O A_{i t}= & \beta_{0}+\beta_{1} L V_{i t}+\beta_{2} L Q_{i t}+\beta_{3} R V_{i t}+\beta_{5} P R_{i t}+\beta_{5} \\
& F S_{i t}+\beta_{6} C O V_{i t}+\varepsilon_{t l}(1) \\
R O E_{i t}= & \beta_{0}+\beta_{1} L V_{i t}+\beta_{2} L Q_{i t}+\beta_{3} R V_{i t}+\beta_{5} P R_{i t}+\beta_{5} \\
& F S_{i t}+\beta_{6} C O V_{i t}+\varepsilon_{t l}(2)
\end{aligned}
$$

Description: LV (leverage); LQ (liquidity); RV (revenue); FS (firm size); COV (COVID-19).

Where $i$ represents the individual firm, and $t$ represents the year. ROA and ROE are the dependent variables in this study. Meanwhile, leverage, liquidity, revenue, profitability, firm size, and COVID-19 are independent variables in this study. The taking of variables refers to several previous studies, as shown in Table 1.

\section{Firms Financial Performance}

According to Gitman and Zutter (2015), ratio analysis is a method of calculating and interpreting corporate financial ratios that aim to assess firm performance.
Ratios can be an alternative to comparing companies of different sizes by calculating and comparing their financial ratios (Ross et al. 2015). A profitability ratio is a tool that companies can use to measure the firm's ability to generate profits. According to Gitman and Zutter (2015), there are several measuring tools or profitability ratios, namely the common-size income statement, gross profit margin (GPM), operating profit margin, net profit margin, earnings per share (EPS), return on total assets (ROA). ) return on equity (ROE). The most commonly used profitability ratios are ROA and ROE. That can be proved by the many previous studies that used these two tools to measure financial performance, some of which are research from Palaniappan (2017), Assenga et al. (2018), and Matar and Eneizan (2018).

The World Health Organization (WHO) has declared COVID-19 a global pandemic and appealed to the world health sector and the government to take it seriously (McKibbin and Fernando, 2020). Previous research was conducted by Kim et al. (2020) regarding the impact of the epidemic on financial performance. The results showed that the epidemic has an impact on the firm's financial performance. The results of a similar study by Seo et al. (2013) and Zhan \& Chen (2013) that the epidemic affects the firm's financial performance. According to Aifuwa et al. (2020), COVID-19 has a negative impact on the firm's financial performance. Hence, the hypothesis is as follow:

H1. COVID-19 has a positive impact on the firm's financial performance

Table 1. Research variable

\begin{tabular}{llll}
\hline Variable & Symbol & Formula & References \\
\hline Return on Asset (Y1) & ROA & Net Profit / Total Asset & Assenga et al. (2018) \\
Return on Equity (Y2) & ROE & Net Profit / Total Equity & Assenga et al. (2018) \\
Leverage (X1) & LV & Total Debt / Total Equity & Matar and Eneizan (2018) \\
Liquidity (X2) & LQ & Current Asset / Current Liability & Matar and Eneizan (2018) \\
Revenue (X3) & RV & ln (total revenue) & \\
Profitability (X4) & PR & Gross Profit / Sales & Batchimeg (2017) \\
Firm size (X5) & FS & ln (total asset) & Assenga et al. (2018) \\
COVID-19 (X6) & COV & $0=$ before COVID-19 & \\
& & $1=$ during COVID-19 & \\
\hline
\end{tabular}


Leverage is a policy in obtaining sources of funds and is used to purchase firm assets accompanied by fixed costs that aim to increase shareholders' return (Gitman and Zutter, 2015). Leverage can be measured using the Debt to Equity Ratio (DER), which compares the firm's total debt with the total equity held (Matar and Eneizan, 2018). Based on the results of previous research from Matar and Eneizan (2018), it is stated that leverage has a negative impact on the firm's financial performance. Different research results are found in research by Alaryan (2017), who explained that leverage has a positive impact on the firm's financial performance. Hence, the hypothesis is as follow:

H2. Leverage has a positive impact on the firm's financial performance

According to Gitman and Zutter (2015), liquidity describes a firm's capability to pay its short-term debt using its current assets. Liquidity is a measure by calculating the ratio of current assets to current liabilities. Durrah et al. (2016) found that liquidity has a positive impact on return on assets. Hence, the hypothesis is as follow:

H3. Liquidity has a positive impact on the firm's financial performance

Company development and growth can obstruct when accessibility in obtaining funds is problematic. Fixed income is one of the firm's primary sources of capital. According to Wamiori et al. (2016), sales revenue is the primary source of firm financing. The results of their research show that sales impact the firm's financial performance. The same research results are explained by Matar and Eneizan (2018) that revenue has a positive impact on the firm's financial performance. Hence, the hypothesis is as follow:

H4. Revenue has a positive impact on the firm's financial performance

Profit shows how well the firm's management performs in the choice of investment and funding decisions. The profitability ratio measures the level of firm management's effectiveness in generating a return on sales, total assets, and shareholder investment. Matar and Eneizan (2018) found a positive effect between profitability on the firm's financial performance in their research. The results of this study are also in line with research from Bayaraa (2017), which explains that profitability affects financial performance. Hence, the hypothesis is as follow:

H5. Profitability has a positive impact on the firm's financial performance.
Firm size can determine from the total assets owned by the firm (Gitman and Zutter, 2015). Previous research from Alaryan (2017) states that firm size has a positive impact on financial performance. The results of this study are also in line with Abdelkarim and Alawneh, 2008), which found a positive influence between firm size on the firm's financial performance. However, the study results differed from Yuan et al. (2008), which shows that companies with large sizes are more susceptible to agency problems. There is a negative influence between firm size on financial performance. Different research results also mentioned Assenga et al. (2018) that firm size does not affect the firm's financial performance. Hence, the hypothesis is as follow:

H6. Firm size has a positive impact on the firm's financial performance

Every company has a main goal that needs to be achieved, namely the welfare of shareholders where the company must have good performance. To improve performance, companies must also be able to maintain and improve their financial performance by using the best possible assets so that they can generate high levels of profit. The Z-score analysis and the panel data regression method in this research was used to analyze the firm's financial health and determine the variables that affect the firm's financial performance. Based on the hypothesis, the research model is formulated as below in Figure 1.

\section{RESULTS}

\section{XYZ Group's Financial Performance and Financial Distress in the Period Before and During COVID-19}

The financial performance of XYZ Group experienced a fluctuating trend both in the period before COVID19 (September 2019 to February 2020) and during the COVID-19 period (March 2020 to August 2020), as in Figure 2 below. This study focuses more on financial performance, which is proxied using the ROA value because the comparison of net income and total assets is more relevant in explaining the firm's financial condition. On the other hand, the ROE value is not representative because there is a negative net income value and the firm's equity value simultaneously, which causes the ROE value to be positive in several months of research. Therefore, this study only uses ROA as an indicator in assessing the financial performance of the XYZ Group poultry farming company. 
Based on Figure 2, several months have a negative ROA value, like in April 2020, where the firm revenue decline. One of the causes of the decline in firm revenue is the low price of broilers. In that month, the cost of broiler had fallen to Rp 7.000 per kilogram. However, XYZ9 Group managed to increase its return on assets in May and June 2020 to 8\%.

In addition, this study also looks at the firm's financial health and analyzes the possibility of financial distress in the firm. Financial distress can occur when a firm experiences losses on an ongoing basis, thereby disrupting cash flow and paying the firm's short-term debt. The six companies studied all showed a Z-score below 1,23 both before COVID-19 (period 1) and during COVID-19 (period 2) in Table 2.

The distress zone faced by the firm during the research period is one of the impacts of the decline in the net income for several consecutive months. The decrease in income results in the erosion of retained earnings and decreases the level of financial health of the firm when measured based on the z-score model. The financial health of the firm has been in a state of distress since before entering the COVID-19 period, so the presence of COVID-19 has no impact on the firm's financial health if it is seen based on the $\mathrm{z}$-score value in period 1 and period 2. Until now, the XYZ Group poultry farming company is still continues to sustain, seen at several points (months) has increased in revenue.

\section{Result of Panel Data Regression Analysis}

In the regression test, an R-squared value of $89.3675 \%$ is obtained, this value explains that the variation in the ROA value that can be explained by the independent variables in the model, namely leverage, liquidity, revenue, profitability, company size and COVID-19, then the remaining $10.633 \%$ is explained by other variables not included in the model. The probability value obtained from the F-statistic is 0.0000 and the value of Adj. R squared is 0.883850 as shown in Table 3.

The regression results show that revenue has a significant negative impact on the firm's financial performance. In contrast, the firm's profitability and size positively affect the firm's financial performance. Meanwhile, leverage, liquidity and COVID-19 have the result that they do not affect the firm's financial performance.

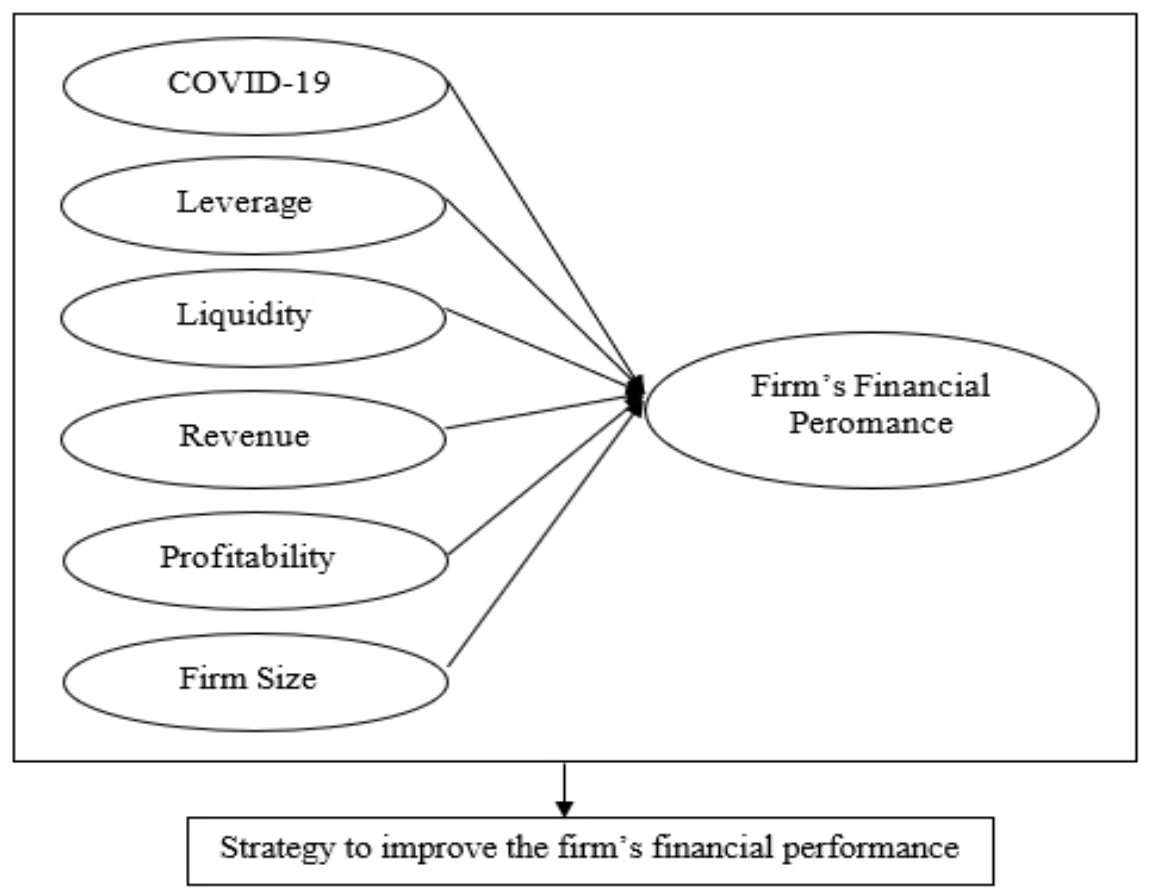

Figure 1. Research model 


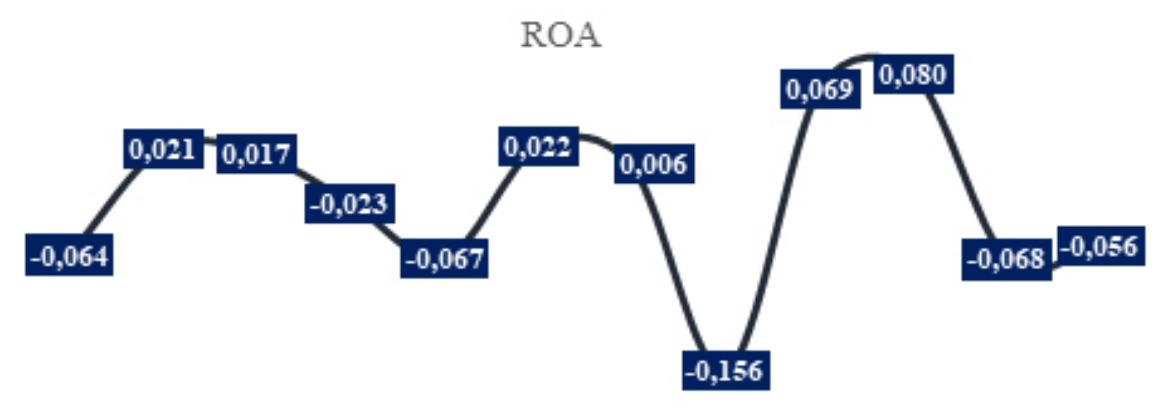

Sept Olt Nov Dec Jan Feb Mar Apr May Jun Jul Aug

$\begin{array}{llllllllllll}2019 & 2019 & 2019 & 2019 & 2020 & 2020 & 2020 & 2020 & 2020 & 2020 & 2020 & 2020\end{array}$

Figure 2. XYZ Group's financial performance based on ROA proxies before and during COVID-19

Table 2. The results of the XYZ Group z-score analysis in the period before and during COVID-19

\begin{tabular}{lcll}
\hline \multicolumn{1}{c}{ Firm's Name } & Period & Z-Score & Finding \\
\hline PT.AAA & $1^{\text {st }}$ & 0,046 & Distress Zone \\
& $2^{\text {nd }}$ & $-0,283$ & Distress Zone \\
PT.BBB & $1^{\text {st }}$ & 0,038 & Distress Zone \\
& $2^{\text {nd }}$ & $-0,452$ & Distress Zone \\
PT.CCC & $1^{\text {st }}$ & 0,101 & Distress Zone \\
& $2^{\text {nd }}$ & $-0,009$ & Distress Zone \\
PT.DDD & $1^{\text {st }}$ & $-0,301$ & Distress Zone \\
& $2^{\text {nd }}$ & $-0,587$ & Distress Zone \\
PT.EEE & $1^{\text {st }}$ & $-1,285$ & Distress Zone \\
& $2^{\text {nd }}$ & $-2,700$ & Distress Zone \\
PT.FFF & $1^{\text {st }}$ & $-0,478$ & Distress Zone \\
& $2^{\text {nd }}$ & $-0,475$ & Distress Zone \\
\hline
\end{tabular}

\section{COVID-19 and Firm's Financial Performance}

The results of this study indicate that COVID-19 does not have a significant impact on the firm's financial performance (H1 is rejected). This explains that the outbreak of COVID-19 does not affect the increase or decrease in the firm's financial performance so that companies can continue to survive and develop their business despite the COVID-19 conditions. At the beginning of the COVID-19 outbreak in Indonesia, there was a rush. Where people stockpile the foods, including broiler chickens. Then in the early months of the PSBB, April, the company began to experience a decline in demand accompanied by a decrease in chicken prices to reach the lowest point of Rp. 7000/kilogram due to the abundant availability of broiler chickens in the market. However, before the entry of the month of Ramadan (May) and Eid al-Fitr (June), the demand for broiler chicken needs is very high so that the price of broiler chickens is corrected to Rp. 24000/kilogram.
Table 3. The impact of leverage, liquidity, revenue, profitability, firm size and COVID-19

\begin{tabular}{lcc}
\hline \multicolumn{1}{c}{ Variabel } & Coefficient & Prob \\
\hline C & -0.435784 & 0.1089 \\
LV & 0.001044 & 0.4467 \\
LQ & 0.006789 & 0.8049 \\
RV & $-0.034927^{*}$ & 0.0022 \\
PR & $0.414755^{*}$ & 0.0000 \\
FS & $0.051190^{*}$ & 0.0082 \\
CV & -0.003118 & 0.5978 \\
\hline R-squared & 0.893666 & \\
Adj. R2 & 0.883850 & \\
F-statistics & 91.04647 & \\
Prob. F-statistics & 0.000000 & \\
\hline
\end{tabular}

This can be the reason that COVID-19 does not fully affect the company's financial performance. The crisis in the broiler industry has occurred since before 2019. This was due to the oversupply of DOC and resulted in the oversupply of broiler chickens. So a factor that has a significant effect is the decrease in demand for livebird broilers at the beginning of the pandemic, which is thought to be due to changes in people's behaviour in meeting household consumption needs. Then since the PSBB was enacted, people have started to reduce their intensity of going out of the house so they prefer to buy products from cold supply chains or frozen carcasses and processed and ready-to-eat food products.

Kolluri et al. (2020) stated that demand for broilers in India had experienced a decline in income from January to March, but demand for broilers increased again in May. In addition, there was an increase in broiler prices in May when compared to the previous month. One of the factors that increase the price of broilers is the 
increase in the amount of consumption and the deficit in the supply of broilers. According to Pu and Zhong (2020), the distribution of livestock and pig products in China was stopped in several areas at the beginning of the outbreak of COVID-19 in Wuhan. This is due to the suspicion of potential transmission of the virus through these products, resulting in an overstock of broilers in breeders' cages, which reached 21.64 million tons of broilers in March 2020 during the pandemic. In Indonesia, Pinsar (2020) shows that during the COVID19 period, the phenomenon of decreasing livestock broiler prices, especially in the West Java region, had experienced a decline in prices in March and April to reach IDR 7,000 per kilogram, but prices rose again in the following months.

\section{Leverage and Firm's Financial Performance}

Based on the leverage regression test results on the firm's financial performance, it shows that there is no influence between leverage on the firm's financial performance as measured by ROA (H2 rejected). The result indicates that the ups and downs of leverage do not affect the firm's rate of return based on the number of assets owned (ROA). The results of this study are not in line with research by Alaryan (2017) and Matar and Eneizan (2018), which explain that leverage has a positive impact on the firm's financial performance. The higher the level of debt the firm has, the higher the firm's financial performance. Debt is a source of funding for the firm. When the firm can still obtain a source of funds from debt, the firm can still carry out its business activities and pay its debts in principal and fixed costs. According to Khan and Ibrahim (2017), companies need to monitor and must be able to manage their debts properly so that they can increase profitability and avoid bankruptcy. This is because XYZ Group's assets do not only consist of company-owned assets but also leased assets and third-party assets managed by joint operations. So that the level of debt has no significant effect on the company's return based on assets owned (ROA).

\section{Liquidity and Firm's Financial Performance}

The results showed that liquidity did not affect the firm's financial performance (H3 rejected). These results explain that the rise and fall of corporate liquidity will not affect the firm's financial performance. This result contradicts the results of a study by Durrah et al. (2016) and Demirgunes (2016), which show that liquidity positively affects the firm's financial performance as measured using ROA. However, the study results are in line with Bayaraa (2017) research that there is no statistical relationship between liquidity and the firm's financial performance. Ayako et al. (2015) also did not find any impact on liquidity on financial performance statistically. These results explain that the increase or decrease in liquidity does not affect the firm's financial performance.

Based on the XYZ Group's financial statements, it explains that the company has a level of liquidity that tends to be stable. The liquidity level of all XYZ Group companies studied had a stable trend in conditions before COVID-19 and during the COVID-19 period. There are only small changes in the amount of liquidity from one period to the next. This causes the rise and fall of the company's liquidity level does not significantly affect the company's financial performance.

\section{Revenue and Firm's Financial Performance}

Based on the revenue regression test results on the firm's financial performance, it was found that there was a negative significant impact between revenue on financial performance on the ROA proxy ( $\mathrm{H} 4$ rejected). These results are in line with the research of Wamiori et al. (2016), which shows that revenue affects the firm's financial performance. According to Wamiori et al. (2016), the level of sales is a source of firm financing, thus affecting the firm's financial performance. This shows that the increase and decrease in revenue will affect the firm's financial performance. Volatility from revenue has a significant negative impact on the firm's financial performance as measured by ROA. Therefore, firm management needs to pay more attention and supervise the value of revenue not to reduce the firm's financial performance (Kanini, 2020). Based on XYZ Group's financial statements, the company's revenue decreased and caused accumulated losses. This causes a decrease in the company's ROA value.

\section{Profitability and Firm's Financial Performance}

The results show a positive influence between profitability on the firm's financial performance (H5 accepted). The results of this study are in line with previous research by Bayaraa (2017), which explains that profitability affects the firm's financial performance. Matar and Eneizan (2018) also found a significant positive impact between profitability on the 
firm's financial performance. So, the higher the level of profitability, can make the firm's financial performance higher.

Based on XYZ Group's financial statements, it can be seen that when the firm's profitability increases, the firm will experience a decrease in the value of accumulated losses recorded on the equity side. It will automatically affect the company's equity and return on equity. If previously the company experienced low profitability but then in the next period the firm experienced an increase in profitability, this will make the amount of losses in the previous period closed which is marked by a reduced amount of accumulated losses in the firm's equity value.

\section{Firm size and Firm's Financial Performance}

The results showed a positive influence between firm size and firm financial performance (H6 accepted). The work shows that the bigger the firm is considered to affect the firm's ability to earn profits. The greater the size of the firm, the more maximum the utilization of total assets becomes profit. The results of this study are in line with research from (Abzari et al. 2012) which explains that the high number of assets in a firm will make the firm more stable in terms of its finances. Alaryan (2017) also explains in his research that firm size positively affects the firm's financial performance as measured by ROA. Total assets reflect the firm's financial stability.

The size of the firm in this study is calculated based on the number of assets owned by the firm, so the results of the study will be directly proportional to the firm's rate of return when viewed based on the number of assets owned (ROA). Then the firm's operational activities in the poultry sector also require large assets in order to generate a large return or rate of return as well. Such as the need for assets in the form of cages to support broiler poultry farming operations. XYZ Group's own assets consist of several types of ownership, namely company property and leased assets as well as third party assets managed by joint operations.

\section{Managerial Implications}

Based on the study results, this formulated alternative strategy, namely based on the results of the z-score test (Table 2). It indicates that there were problems with financial health, so the company needed to maintain its cash flow by extending the payment period for the firm's production debt through renegotiation with the supplier. Then shorten the payment period for customer receivables to get a better turnover.

The results also show that profitability has a positive impact on the firm's financial performance. Companies can improve the efficiency of the cost of goods sold by evaluating the selection of the best livestock production facilities to produce the expected weight of chickens at harvest time at the lowest possible cost. In addition, companies can continue to innovate in cage technology, one of which is by using closed-house cages. Close house cages are considered capable of increasing the efficiency of raising chickens when compared to semiclosed houses. Companies can increase the company's working capital through funding from holding companies to improve company operations.

The results also show that firm size has a positive impact on the firm's financial performance. Companies can increase the rate of return on assets by increasing the number of assets. The company needs to continue to expand its cooperation network with third parties, especially in terms of asset leasing and joint operations in broiler farming activities.

The results also show that profitability has a positive impact on the firm's financial performance. Companies can improve the efficiency of the cost of goods sold by evaluating the selection of the best livestock production facilities to produce the expected weight of chickens at harvest time at the lowest possible cost. In addition, companies can continue to innovate in cage technology, one of which is by using closed-house cages. Close house cages are considered capable of increasing the efficiency of raising chickens when compared to semiclosed houses. Companies can increase the company's working capital through funding from holding companies to improve operationally.

The results also show that firm size has a positive impact on the firm's financial performance. Companies can increase the rate of return on assets by increasing the number of assets. The company needs to continue to expand its cooperation network with third parties, especially in terms of asset leasing and joint operations in broiler farming activities. 


\section{CONCLUSIONS AND RECOMMENDATIONS}

\section{Conclusions}

This study uses ROA as an indicator of financial performance. The financial performance of XYZ Group experienced a fluctuating trend both in the period before COVID-19 and during the COVID-19 period. Then, this study also analyzes financial distress based on the z-score. The broiler farming company XYZ group has problems with its financial health if analyzed based on the z-score. The resulting z-score shows that the firm's financial condition had experienced problems before the COVID-19 era and worsened after entering the COVID-19 period. However, on the other hand, based on its financial performance as measured by return on assets, the firm's financial performance is not significantly affected by COVID-19. That result shows that the firm's rate of return is not affected by the COVID-19 phenomenon.

The broiler farming company XYZ group has problems with its financial health if analyzed based on the z-score. The resulting z-score shows that the firm's financial condition had experienced problems before the COVID-19 era and worsened after entering the COVID-19 period. However, on the other hand, based on its financial performance as measured by return on assets, the firm's financial performance is not significantly affected by COVID-19. That result shows that the firm's rate of return is not affected by the COVID-19 phenomenon.

Several other variables in this study affect the firm's financial performance; namely, revenue has a significant negative impact on financial performance. Profitability and firm size have a significant positive impact on financial performance. Companies need to maintain cash flow by extending the life of debt repayments and shortening their debt repayments, and evaluating the selection of the best livestock production facilities and technology to be efficient in the production process. Companies can also increase funding by obtaining additional capital from a holding company before financing from outside parties.

\section{Recommendations}

The results showed that the company experienced problems with its financial health condition, although statistically, COVID-19 did not affect its financial performance. So, the company management should increase the operational funding obtained first through the holding company to improve the firm's cash flow. Company management also needs to continue to make efficient in the operating costs of raising chickens. Future research can discuss sustainability and the role of holding on the performance of broiler farm companies.

\section{REFERENCES}

Aifuwa HO, Saidu M, Aifuwa SA. 2020. Coronavirus pandemic outbreak and firms performance. Management and Human Resource Research Journal 9(4):15-25.

Alaryan LA. 2017. Exploring the role of board characteristics on enhancing financial performance of Jordanian listed companies. Internation Journal of Economics and Finance 9(7): $\quad 99-105 \quad$ https://doi.org/10.5539/ijef. v9n7p99

Altman E. 1968. Financial ratios, discriminant analysis, and the prediction of corporate bankruptcy. The Journal of Finance 23(4): 589-609. https://doi. org/10.1111/j.1540-6261.1968.tb00843.x

Altman E. 2006. Corporate Financial Distress and Bankruptcy. Ed ke-3. New York: John Wiley \& Sons.

Andrade G, Kaplan SN. 1998. How costly is financial (not economic) distress? Evidence from highly leveraged transactions that became distressed. The Journal of Finance 53(5): 1443-1493. https://doi.org/10.1111/0022-1082.00062

Assenga MP, Aly D, Hussainey K. 2018. The impact of board characteristics on the financial performance of Tanzanian firms. Corporate Governance: The International Journal of Business in Society 18(6):1089-1106. https://doi.org/10.1108/CG09-2016-0174

Ayako A, Githui T, Kungu G. 2015. Financial performance of firms. Perspectives of Innovations, Economics and Business 15(2): 84-94. https://doi.org/10.15208/pieb.2015.08

Bahari N, Mustadjab MM, Hanani N, Nugroho BA. 2012. Analisis contract farming usaha ayam broiler. Jurnal Agro Ekonomi 30(2):109-127. https://doi.org/10.21082/jae.v30n2.2012.109127

Bayaraa B. 2017. Financial performance determinants of organizations: the case of Mongolian companies. 
Journal of Competitiveness 9(3):22-33. https:// doi.org/10.7441/joc.2017.03.02

[Ditjennak] Direktorat Jenderal Peternakan dan Kesehatan Hewan. 2015. Informasi publik. https://ditjennak.pertanian.go.id. [4 Nov 2020].

Durrah O, Rahman AAA, Jamil SA, Ghafeer NA. 2016. Exploring the relationship between liquidity ratios and indicators of financial performance: An analytical study on food industrial companies listed in Amman Bursa. International Journal of Economics and Financial Issues 6(2):435-441.

Gitman JLdanZutter CJ.2015. Principles of Managerial Finance. Ed ke-13. England: Pearson.

Kanini S. 2020. Evaluation of the nexus between revenue volatility from commodity sales and financial performance of manufacturing. International Academic Journal of Economics and Finance 3(5):238-250.

Khan MA, Ibrahim MY. 2017. Improving firm financial performance through corporate governance mechanism in Malaysian listed companies : empirical study approach. Global Business and Management Research: An International Journal 9(1):28-39.

Kolluri G, Tyagi JS, Sasidhar PVK. 2020. Research Note: Indian poultry industry vis-à-vis coronavirus disease 2019: a situation analysis report. Poultry Science. https://doi.org/10.1016/j. psj.2020.11.011

Maisana Z, Hartoyo S, Fahmi I. 2012. Pendekatan total quality management produk broiler tolakan. Jurnal Manajemen \& Agribisnis 9(3): 163-172.

Matar A, Eneizan B. 2018. Determinants of financial performance in the industrial firms: evidence from Jordan. Asian Journal of Agricultural Extension, Economics \& Sociology 22(1):1-10. https://doi.org/10.9734/AJAEES/2018/37476
Mohammed S. 2016. Bankruptcy prediction by using the Altman Z-score model in Oman: A case study of raysut cement company SAOG and its subsidiaries. Australasian Accounting, Business and Finance Journal 10(4):75-85. https://doi. org/10.14453/aabfj.v10i4.6

[OECD] Organisation for Economic Co-operation and Development. 2020. Meat Consumption. https:// data.oecd.org/agroutput/meat-consumption.htm. [29 May 2020]

Outecheva N. 2007. Corporate financial distress: an empirical analysis of distress risk [dissertation]. Bamberg: University of St.Gallen.

Palaniappan G. 2017. Determinants of corporate financial performance relating to board characteristics of corporate governance in Indian manufacturing industry: An empirical study. European Journal of Management and Business Economics 26(1):67-85. https://doi.org/10.1108/ EJMBE-07-2017-005

[Pinsar] Perhimpunan Insan Perunggasan Rakyat Indonesia. 2020. Fluktuasi Harga Livebird di Jawa Barat. https://pinsarindonesia.com. [29 May 2020]

Pu M, Zhong Y. 2020. Rising concerns over agricultural production as COVID-19 spreads: Lessons from China. Global Food Security 26: 100409. https:// doi.org/10.1016/j.gfs.2020.100409

Ross SA, Westerfield RW, Jaffe J, Lim J, Tan R, Wong H. 2015. Corporate finance: asia global edition. Asia Global ed. Mc-Graw-Hill Education: New York.

Wamiori MG, Gregory N, Maurice S. 2016. Effect of access to finance on financial performance of manufacturing firms in Kenya. The Strategic Journal of Business and Change Management 3(4):403-421. 